\title{
Michigan Residential \\ No. 2 Fuel Oil and Propane Price Survey \\ for the 1990/91 Heating Season
}

\author{
Final Report \\ October 1991
}

\section{DISCLAIMER}

This report was prepared as an account of work sponsored by an agency of the United States Government. Neither the United States Government nor any agency thereof, nor any of their employees, makes any warranty, express or implied, or assumes any legal liability or responsibility for the accuracy, completeness, or usefulness of any information, apparatus, product, or process disclosed, or represents that its use would not infringe privately owned rights. Reference herein to any specific commercial product, process, or service by trade name, trademark, manufacturer, or otherwise does not necessarily constitute or imply its endorsement, recommendation, or favoring by the United States Government or any agency thereof. The views and opinions of authors expressed herein do not necessarily state or reflect those of the United States Government or any agency thereof.

\section{Prepared by \\ The Michigan Public Service Commission Office of Planning Policy and Evaluation}

Michigan Department of Commerce 


\section{INTRODUCTION}

This report summarizes the results of a survey of home heating oil and propane prices over the 1990/1991 heating season in Michigan. The survey was conducted under a cooperative agreement between the State of Michigan, Michigan Public Service Commission and the U.S. Department of Energy (DOE), Energy Information Administration (EIA), and was funded by a grant from EIA.

From October 1990 through May 1991, participating dealers/distributors were called and asked for their current residential retail prices of No. 2 home heating oil and propane. This information was then transmitted to the EIA, bi-monthly using an elestronic reporting system called Petroleum Electronic Data Reporting Option (PEDRO).

The survey was conducted using a sample provided by EIA of home heating oil and propane retailers which supply Michigan households. These retailers were contacted the first and third Mondays of each month. The sample was designed to account for distributors with different sales volumes, geographic distributions and sources of primary supply. It should be roted that this sample is different from the sample used in prior year surveys.

In addition to assisting the EIA meet its Congressional mandate of providing an accurate and timely energy data, the state has made use of the price information to monitor price changes that occurred during the Gulf War.

The DOE has provided grants to a total of 26 states to cover the costs of regular collection of this price data. Michigan's participation in this survey program began in 1979. Midwest states participating in the 1990/91 survey include Illinois, Indiana, Iowa, Kansas, Michigan, Minnesota, Missouri, Nebraska, North Dakota, Ohio, South Dakota, and Wisconsin.

Any questions on this survey should be directed to Jeffrey R. Pillon, Michigan Public Service Commission P.O. Box 30221, Lansing, MI 48909. Phone: (517) 334-6431. 


\title{
RETAIL PRICES FOR NO. 2 HEATING OIL AND PROPANE
}

\begin{abstract}
Retail home heating oil prices began the 1990/91 heating season with the highest prices seen in five years as a result of the sharp increases in crude oil prices following Iraq invasions of Kuwait. In Michigan the average price was $\$ 1.25$ a gallon on October 1, 1990 excluding the four percent Michigan sales tax. Prices peaked later that month, averaging $\$ 1.30$ on October 15. Prices then declined through the balance of the heating season with the lowest price reported on March 18, 1991 of $\$ .93$ per gallon, (see Figure and Table 1). The price range (i.e., the spread between the highest and lowest reported price) was the greatest in November when the range reached 35.9 cents per gallon.
\end{abstract}

The retail price of propane averaged $\$ .97$ a gallon (excluding sales tax) on October 1, peaking in mid-October at $\$ 1.05$ and falling through the remainder of the heating season. The price averaged \$.89 a gallon on March 18, 1991 (see Figure and Table 2). The price range was the greatest in January when the range reached 59.5 cents per gallon. As retail prices fell, the price range narrowed to 34 cents at the end of the heating season closer to the range $i_{11}$ prices seen during October and November.

The range in prices is a result of differences in the rate at which reductions in wholesale price changes are reflected in retail prices, differences in wholesale prices between major oil companjes, the degree of mark-up between wholesale and retail and differences in transportation expenses.

\section{A COMPARISON OF MICHIGAN, REGIONAL AND NATIONAL PRICES}

Michigan No. 2 fuel oil prices for residential customers have typically been below the national average prices over the 1985 to 1990 period. The average annual price in Michigan was three cents below the national average over this time frame, (see Figure and Table 3).

Figure and Table 3 also show the longer term price movements for home heating oil. The price drop seen in 1986 is a result of the collapse in crude oil prices that occurred that year. The upward price trend seen over the following period reflects crude oil price increases and the general effect of inflation since all prices are shown in nominal dollars. The price spike seen in the winter of $1989 / 90$ resulted from much colder than normal weather that occurred between the end of November and early January and natural gas curtailments in the Northeast that contributed to the distribution problems. The price increases that occurred over the winter of $1990 / 91$ are due to the increases in crude oil prices as a result of the Gulf War.

Looking at a regional level, Michigan's No. 2 fuel oil prices are the highest of seven Midwest states, (see Table 6). On the average, over the 1990/91 heating season, Michigan's price was 4.1 cents per gallons higher than the Midwest average. Part of the higher cost may be due to higher transportation cost for trucking and barge shipments to 
the northern part of the state where heating oil use is proportionately greater. Proximity to pipeline terminals generally tends to hold down prices compared to locations further removed.

Propane Prices show a different regional price pattern from beating oil (see Table 7). Ohio has the highest average propane price followed by Michigan.

\section{CRUDE OIL AND WHOLESALE PRICES}

The retail price of No. 2 fuel oil is driven by the underlying wholesale price and the price of crude oil from which it is derived. Looking at the difference between retail and wholesale prices show's an average gross margin over the heating season of 35 cents per gallon. This figure (the difference between retail and wholesale prices) reflects the cost of transportation, distribution, taxes, insurance, other overhead business expenses, and profit. Seasonal fluctuation in the carry costs of fuel held in inventory is also reflected in this gross margin. Gross margins (retail/wholesale) varied from a low of 24 cents to a high of 41 cents. Some of this variation also reflects a lag between wholesale and retail price changes due to different reporting dates and turn over of product held in inventory.

The average difference between crude oil and wholesale fuel oil prices was 15 cents a gallon. This difference is based on the West Texas Intermediate (WTI) grade of crude oil as a price bench mark, (see Figure and Table 4). Retail prices follow' the general decline in wholesale and crude oil cost over the heating season. Crude oil has different qualities and prices which affect the production cost. The gross difference between crude oil and wholesale prices reflects the average cost of shipping, refining other business expenses, transportation charges for pipeline, rail or barge shipments to terminal locations, and profit. The gross margin (crude oil/wholesale) varies from a high of 21 cents to a low of 8 cents. Some of this variation reflects the lag between wholesale and crude oil prices due to crude oil price contracts for oil in transit and the rate of turn over in refinery inventories.

Propane prices showed a similar pattern to fuel oil prices, (see Figure and Table 5). Retail prices, however, did not decline as much as Midwest wholesale and crude oil prices towards the end of the heating season. The gross margin reached a high of 65 cents a gallon in early February 1991, from the low of 36 cents a gallon on October 1 . By the end of the heating season, they declined to 56 cents, still considerably above the differences seen in October and early November.

The difference between wholesale propane and crude oil prices is negative, which means crude oil is valued higher than propane. This is because propane and other Liquefied Petroleum Gases (LPG) only make up four percent of the petroleum products produced from a barrel of crude oil in 1990. With the much larger demand for gasoline and distillate fuel oil, LPG is priced essentially as a by product of refinery production. In Michigan, LPG accounted for 12 percent of total petroleum use in 1989 with the residential sector the largest user, consuming 439 million gallons or 47 percent of total use, followed by the industrial sector which used 402 million gallons or 43 percent of the total. 


\section{WEATHER INFORMATION}

The demand for residential fuel oil and propane is a function of the average temperatures over the heating season. Weather related demand for beating fuels is typically measured through the use of an indicator called "heating degree days" which is the numeric difference between 65 degrees and the daily mean temperature. Accumulation of these differences gives a relative indication of the heating fuel demand. Figure 6 and Table 8 show the heating degree days based on the Lansing weather station over the 1991 heating season in comparison with the 30 year normal and the 1989-90 leating season. As can be seen in Figure 6, weather during the 1990-91 heating season was generally warmer than normal and considerably warmer than November, December, and January of 1989. The result of the warmer weather would be a reduction in the overall demand for heating fuels which would have a downward pressure on price.

\section{METHODOLOGY}

Thirty-six fuel oil distributors and 22 propane dealers (including one dealer who sells both) were surveyed the first and third Mondays of each month over the heating season. The data was summarized and disseminated by the ELA to the States, Congress, and other government agencies. This provided analysts with information necessary to monitor heating fuels price changes that sesulted from the Gulf War.

\section{General Reporting}

The selected companies were requested to report the average price of residential No. 2 fuel oil and propane sold to customers in the State. Prices were reported to the nearest tenth of a cent; for example, 1.095. The Annual Propane Sales Volumes was reported in thousands of gallons and rounded to the nearest thousand. For example, 6,500 gallons was reported as 7 or 6,400 gallons was reported as 6 .

The No. 2 Fuel Oil Residential Price is defined as the price paid for home delivery of No. 2 fuel oil. Prices were reported exclusive of discounts for payment of cash or within a short period of time.

Propane Residential Price is defined as the "bulk keep full" price paid for home delivery of consumer grade propane intended for use in space heating, cooking, or hot water heaters in residences. Prices were reported exclusive of discounts for payment of cash or withir. a short period of time. If the "bulk keep full" price does not apply to a particular company, the usual price type ("will call" or other) was indicated.

For the purpose of this program, sales to apartment buildings or other multi-family dwellings was excluded. 
Each propane supplier also reported, for the first report only, the approximate annual sales of propane to residential customers in Michigan during the period of September 1, 1989 through August 31, 1990. This was used to establish weights used in developing the average volumetric weighted price.

\section{Survey Dates}

The survey report dates are the first and third Mondays of each month. The specific survey dates were:

October 1 and 15, 1990

November 5 and 19, 1990

December 3 and 17,1990

January 7 and 21, 1991

February 4 and 18, 1991

March 4 and 18, 1991

April 1 and 15, 1991

May 6, 1991

The companies selected to participated were contacted prior to the first date (October 1 , 1990) to notify the respondents of the data elements that would be collected and to identify a mutually agreeable time of telephone calls to confirm the company's contact person provided by the ELA.

\section{Sampling Methodology and Estimation Procedures}

Both the survey sample and method for estimating the average price was developed by EIA and prorided to the states. The following was abstracted from the Winter Fuels Report.

To estimate aggregate propane and No. 2 heating oil price data, the sample weight and volume sales data were applied to the reported price, summed and divided by the sum of the weighted volume. This value was reported as the Michigan price in the Winter Fuels Report.

For the No. 2 heating oil price data, a sample design similar to that used for the Form EIA-782B, "Resellers'/Retailers' Monthly Petroleum Product Sales Report" sample design was used. The sampling frame was an extract of approximately 11,000 companies from the Form EIA-863, "Petroleum Product Sales Survey" conducted in 1989 and containing 1988 sales volume information. A one-way stratified sample design using No. 2 residential distillate from sales volumes for Michigan was used. Stratum boundaries were determined by the Dalenius-Hodges procedure.

Since no volume sales infcrmation existed to predetermine the volume sales of propane dealers, two strata for propane dealers was used. A certainty stratum of the known, large, multi-State dealers was created. These companies were identified using establishment lists obtained in deriving the frame. All other dealers were in a second stratum and a random 
sample from this stratum was selected. Sample weights were calculated as the inverse of the probability $(N / n)$. The name and address list sampling frame was constructed from numerous sources. See the Winter Fuel Report Note 4 for further detail.

\section{Dissemination of Aggregated Data}

After the data was received from Michigan, they were edited and aggregated by the EIA and entered into the Electronic Publication (EPUB) system within four (4) working days of receipt of the States' reports. The survey results were also published by EIA in the EIA Winter Fuels Report (DOE/ELA-0538) which is available by contacting ELA's National Energy Information Center, phone (202) 586-8800.

\section{Confidentiality of Reported Data}

The ELA is responsible for assuring confidentiality of the companies' data to the extent required by law. The data obtained from the ELA selected companies will be kept confidential and not disclosed to the public to the extent that it satisfies the criteria for exemption under the Freedom of Information Act (FOIA), 5 U.S.C. S552, the DOE regulations, 10 C.F.R. S1004.11, implementing the FOIA, and the Trade Secrets Act, 18 U.S.C. S1905.

Response to this survey was mandatory under the Federal Energy Administration Act of 1974 (Public Law 93-275). Data collected for this survey are considered to be confidential and will not be released to the public in a company identifiable manner. A recent decision by the Office of Legal Counsel of the Department of Justice concluded that the EIA Administrator is required to provide company-specific data collected or maintained by EIA to any requesting Federal Government department or agency official for official use (see Section $12 \mathrm{f}$ of the Federal Energy Administration Act of 1974, 15 U.S. C. 771(f)). This ruling revokes any promises of interagency confidentiality expressed in the past. 


\section{LIST OF TABLES AND FIGURES}

Figure and Table 1

Figure and Table 2

Figure and Table 3

Figure and Table 4

Figure and Table 5

Table 6

Table 7

Figure 6

Table 8
Michigan No. 2 Fuel Oil Prices

Michigan Propane Prices

No. 2 Fuel Oil Prices to Residential Consumers

No. 2 Heating Oil -- Residential, Wholesale and Crude Oil Cost Comparison

Propane -- Residential, Wholesale and Crude Oil Cost Comparison

Residential Heating Oil Prices by Region and State

Residential Propane Prices by Region and State

30-Day Cumulative Heating Degree Days

30-Day Cumulative Degree Days 
Figure 1 and Table 1

\section{Michigan No. 2 Fuel Oil Prices}

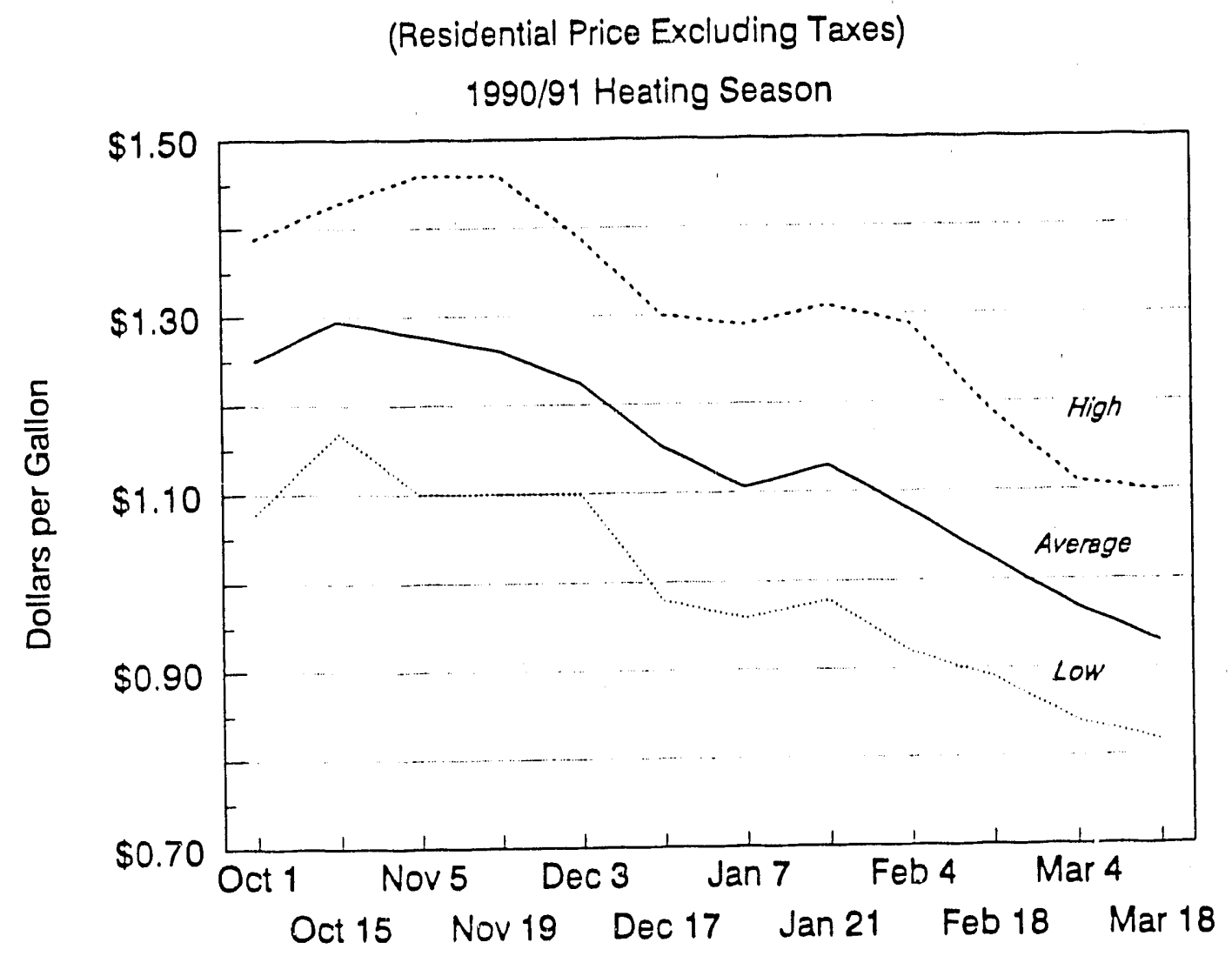

$\begin{array}{lccc}\text { Date } & \text { Low } & \text { Average } & \text { High } \\ \text { October 1 } & 107.9 & 125.1 & 138.9 \\ \text { October 15 } & 116.9 & 129.5 & 142.9 \\ \text { November 5 } & 110.0 & 127.8 & 145.9 \\ \text { November 19 } & 110.0 & 126.1 & 145.9 \\ \text { December 3 } & 109.9 & 122.4 & 138.9 \\ \text { December 17 } & 98.0 & 115.2 & 130.0 \\ \text { January 7 } & 95.9 & 110.5 & 128.9 \\ \text { January 21 } & 97.9 & 113.0 & 131.0 \\ \text { February 4 } & 92.0 & 107.9 & 128.9 \\ \text { February 18 } & 89.0 & 102.3 & 118.9 \\ \text { March 4 } & 84.0 & 97.0 & 111.0 \\ \text { March 18 } & 81.9 & 93.0 & 109.9\end{array}$

Source: Michigan Public Service Commission, State Heating $0 i 1$ and Propane Price (SHOPP) Survey, October 1991. 
Page 9

Figure 2 and Table 2

\section{Michigan Propane Prices}

(Residential Price Excluding Taxes)

1990/91 Heating Season

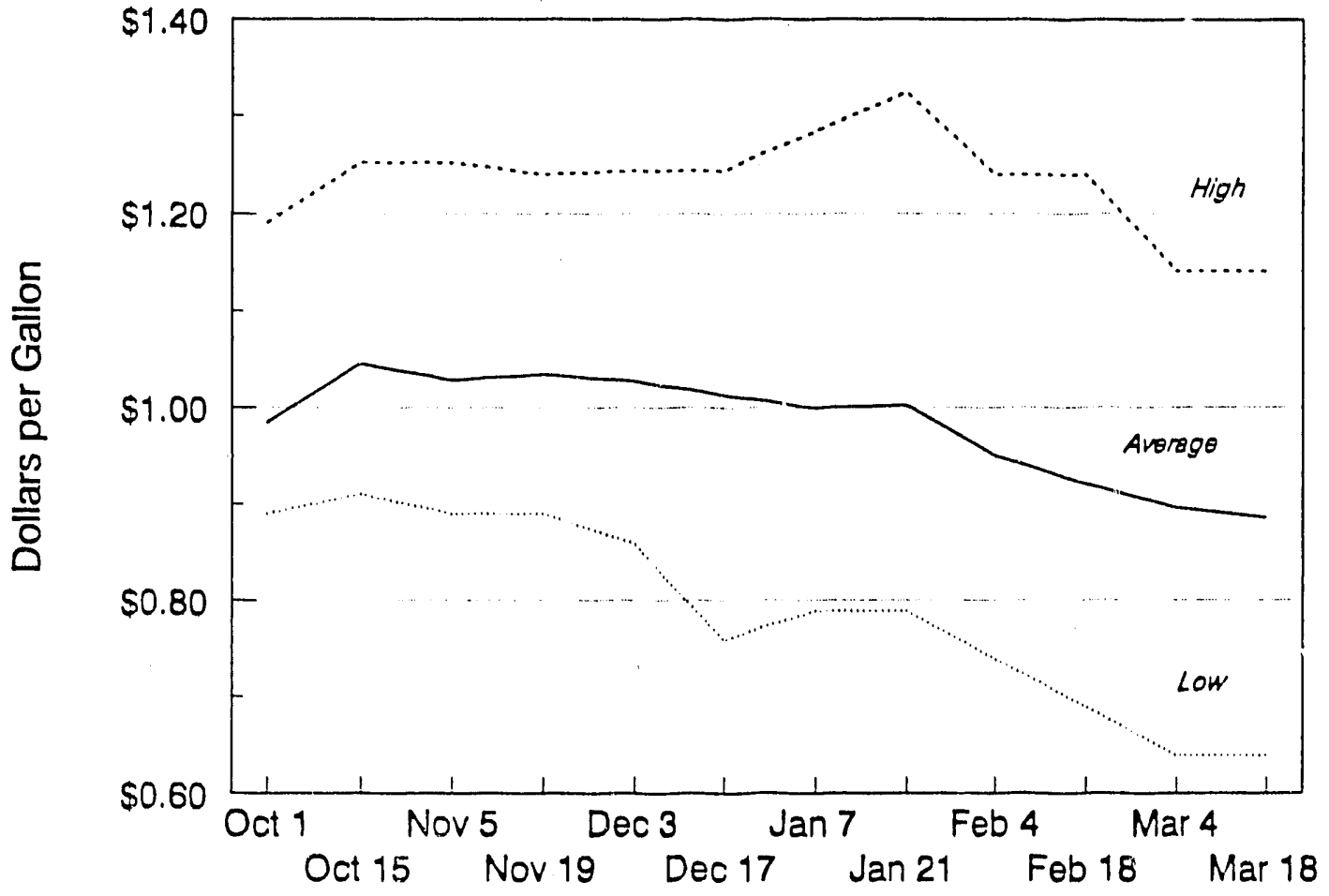

$\begin{array}{lrrr}\text { Date } & \text { Low } & \text { Average } & \text { High } \\ \text { October 1 } & 89.0 & & 119.0 \\ \text { October 15 } & 91.0 & 104.5 & 125.2 \\ \text { November 5 } & 89.0 & 102.9 & 125.2 \\ \text { November 19 } & 89.0 & 103.5 & 124.0 \\ \text { December 3 } & 85.9 & 102.8 & 124.4 \\ \text { December 17 } & 75.9 & 101.4 & 124.4 \\ \text { January 7 } & 78.9 & 100.0 & 128.4 \\ \text { January 21 } & 78.9 & 100.3 & 132.4 \\ \text { February 4 } & 73.9 & 95.1 & 124.0 \\ \text { February 18 } & 68.9 & 92.2 & 124.0 \\ \text { March 4 } & 63.9 & 89.7 & 114.0 \\ \text { March 18 } & 63.9 & 88.6 & 114.0\end{array}$

Source: Michigan Public Service Commission, State Heating $0 i 1$ and Propane Price (SHOPP) Survey, October 1991. 
Figure 3 \& Table 3

No. 2 Fuel Oil Prices to Residential Consumers

(Cents per Gallon Excluding Taxes)

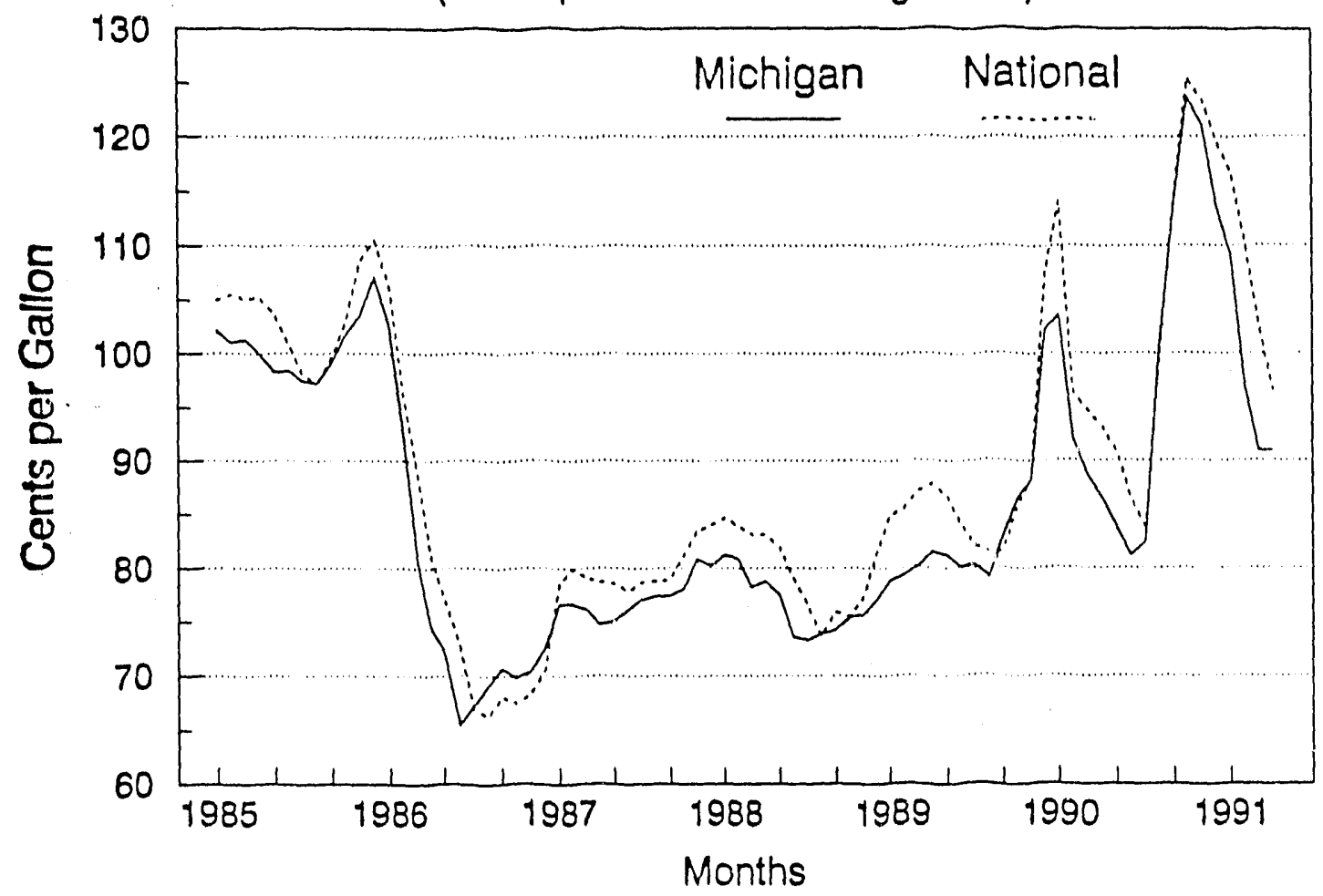

Year

1985

1986

1987

1988

1989

1990

$1991 *$
Michigan

100.6

75.6

77.2

76.6

83.4

99.1

97.0
National

103.5

77.5

79.8

79.7

86.9

103.3

106.6

* Based on a four month average

Source: U.S. Department of Energy, Energy Information Administration Petroleum Marketing Monthly Table 37 
Figure \& Table 4

\section{NO.2 HEATING OIL RESIDENTIAL, WHOLESALE \& CRUDE OIL COST COMPARISON} 1990/1991 Heating Season

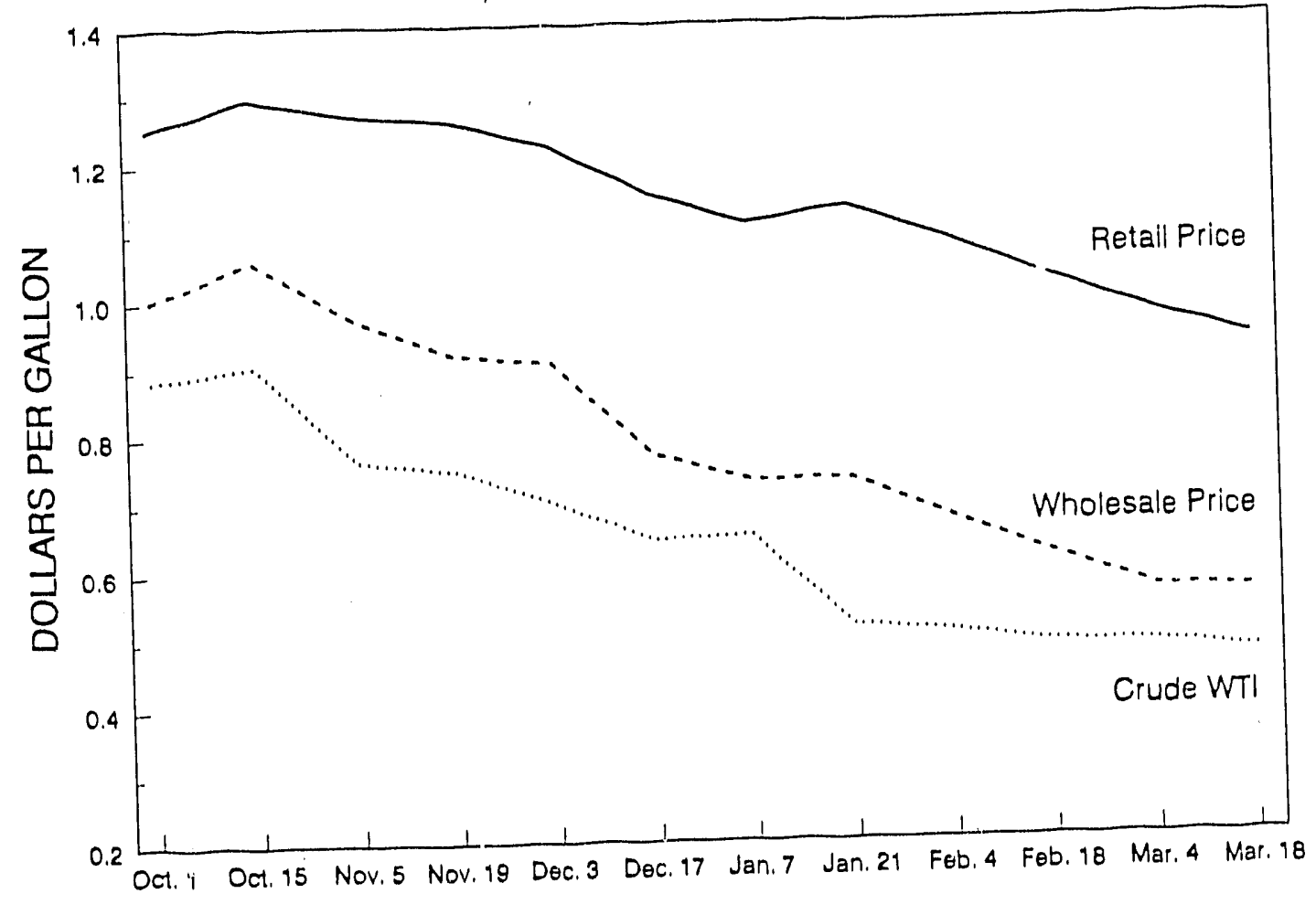

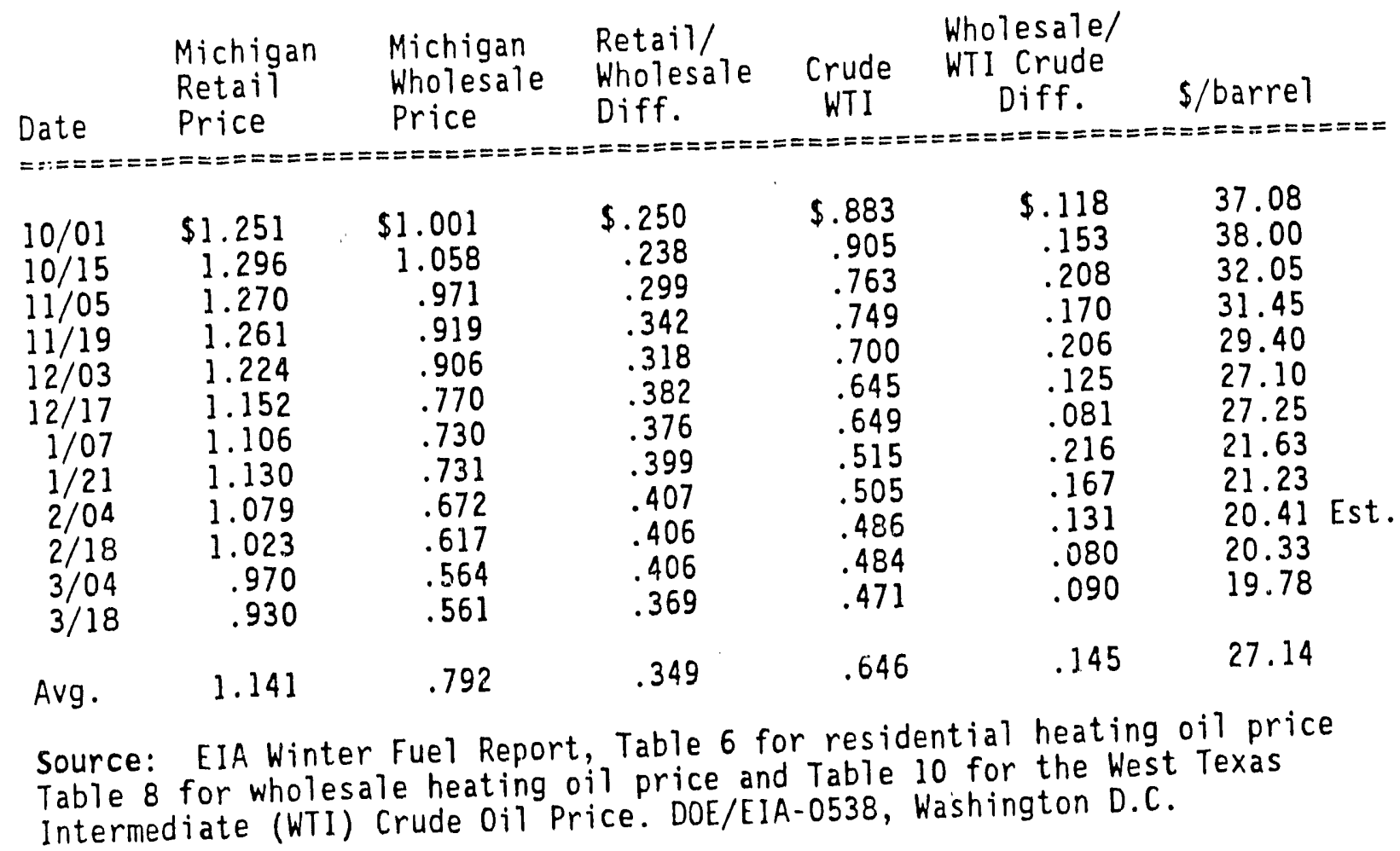


Figure \& Table 5

\section{PROPANE}

\section{RESIDENTIAL, WHOLESALE \& CRUDE OIL COST COMPARISON}

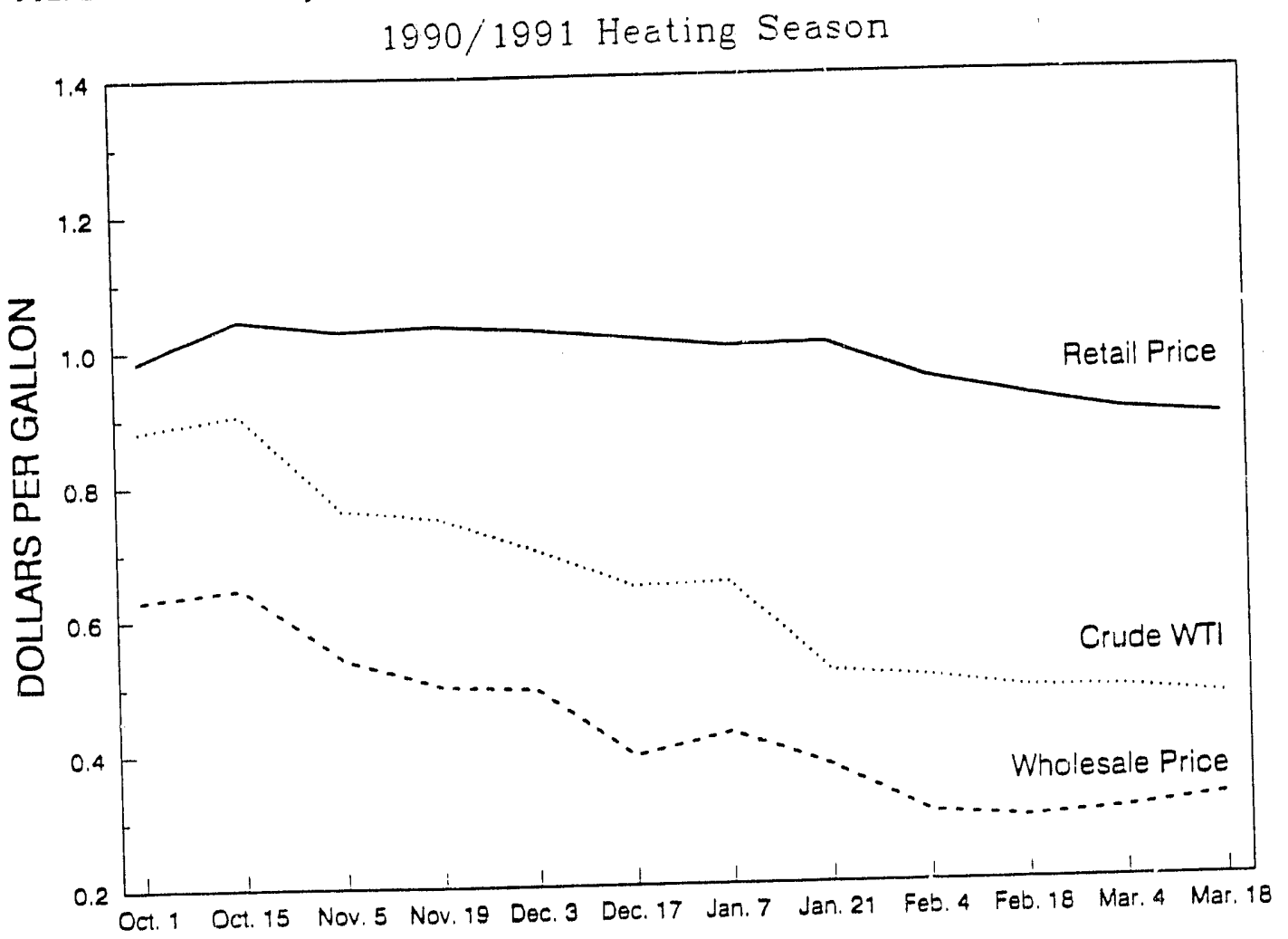

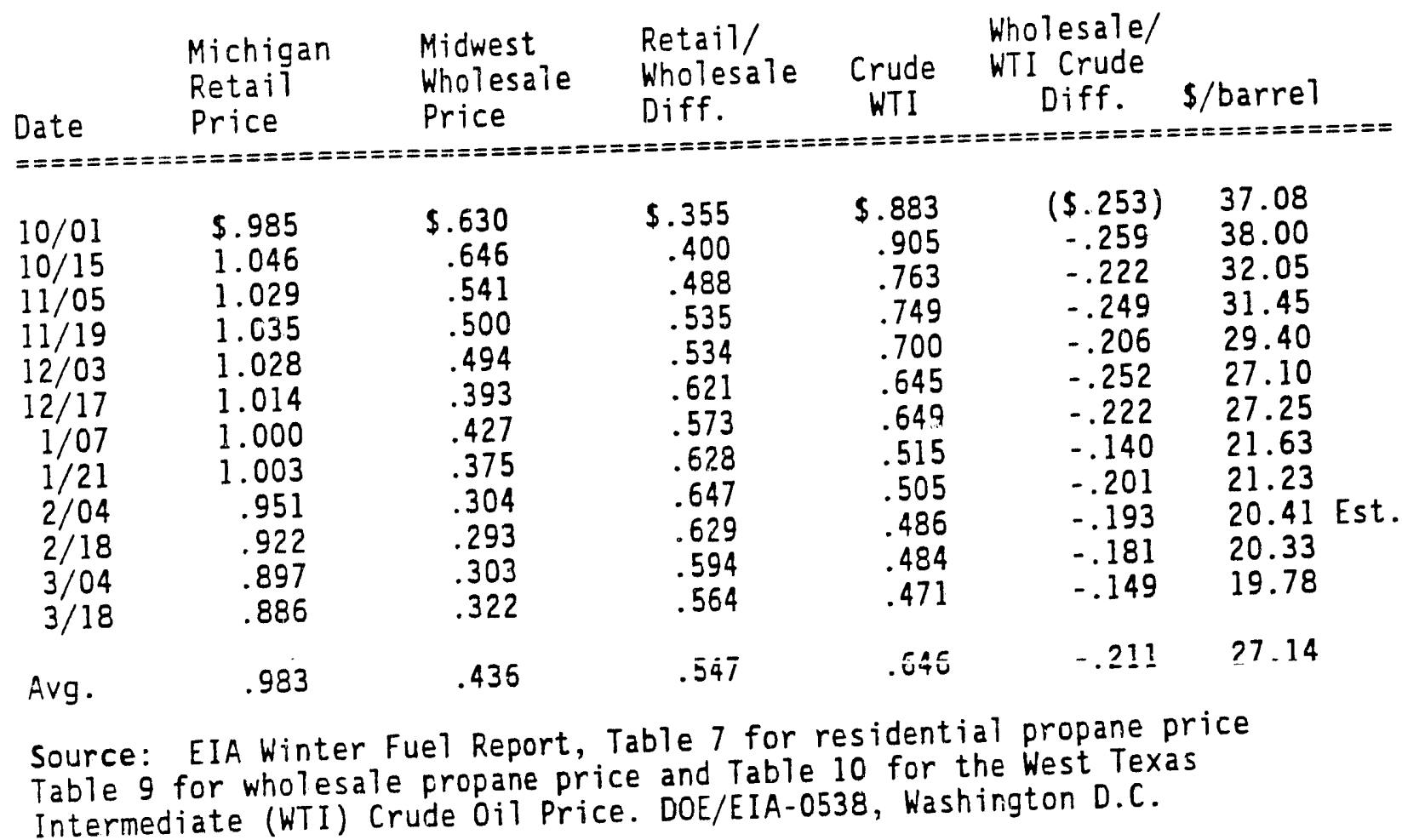




\section{Table 6}

\section{Resideritial Heating 0il Prices by Region and State (Cents per Gallon)}

\begin{tabular}{|c|c|c|c|c|c|c|c|c|c|c|c|c|}
\hline \multirow[b]{2}{*}{ Reglon/State } & \multicolumn{12}{|c|}{ 1990/91 Heating Season } \\
\hline & $10 / 01$ & $13 / 15$ & $11 / 05$ & $11 / 19$ & $12 / 03$ & $12 / 17$ & $01 / 07$ & $01 / 21$ & 0204 & $02 / 18$ & $03 / 04$ & $03 / 18^{F}$ \\
\hline Averago & 127.9 & 133.2 & 130.4 & 128.9 & 128.5 & 123.9 & 120.5 & 122.6 & 118.0 & 114.5 & 109.7 & 105.4 \\
\hline East Coast (PADD I) & 129.6 & 134.8 & 131.9 & 130.3 & 130.3 & 126.6 & 123.2 & 125.4 & 121.2 & 118.1 & 113.5 & 108.8 \\
\hline New England (PADD D) & 130.6 & 134.6 & 128.3 & 125.7 & $126.8^{\circ}$ & 121.4 & 118.2 & 121,1 & 117.3 & 114.9 & 109.2 & 105.0 \\
\hline Connecticut & 128.5 & 134.7 & 135.5 & 132.7 & 133.1 & 128.0 & 125.4 & 126.6 & 124.0 & 121.6 & 915.5 & 110.5 \\
\hline Maine & 127.7 & 131.4 & 118.6 & 112.6 & 116.1 & 106.9 & 108.6 & 111.9 & 105.6 & 104.3 & 97.5 & 93.0 \\
\hline Massachusetts & 133.4 & 136.2 & 126.4 & 124.3 & 125.4 & 121.2 & 116.0 & 120.8 & 116.6 & 113.7 & 108.9 & 104.7 \\
\hline New Hampshire & 129.2 & 132.4 & 127.4 & 124.6 & 126.0 & 116.6 & 114.8 & 117.6 & 112.4 & 110.0 & 104.7 & 97.6 \\
\hline Rhode Island & 131.3 & 134.0 & 130.1 & 129.5 & 130.6 & 124.9 & 123.2 & 123.6 & 121.2 & 120.8 & 114.8 & 111.3 \\
\hline Vermont & 125.5 & 132.7 & 131.1 & 130.5 & 128.6 & 126.0 & 122.4 & 121.0 & 119.8 & 116.8 & 112.5 & 109.7 \\
\hline Central Allantic (FADDM) & 129.5 & 135.1 & 133.9 & 132.9 & 132.4 & 129.7 & 126.2 & 128.2 & 123.9 & 120.6 & 116.6 & 111.7 \\
\hline Delaware & 123.0 & 130.3 & 126.4 & 124.2 & 124.6 & 118.7 & 116.9 & 118.6 & 114.9 & 112.8 & 107.5 & 102.0 \\
\hline District of Columbia & 123.1 & 135.0 & 135.6 & 135.1 & 136.1 & 132.4 & 128.8 & 128.2 & 125.4 & 122.0 & 118.2 & 115.4 \\
\hline Maryland & 126.9 & 131.9 & 130.9 & 129.4 & 130.0 & 125.7 & 123.2 & 124.4 & 118.8 & 116.4 & 112.0 & 107.2 \\
\hline New Jersey & 131.7 & 137.7 & 136.0 & 134.1 & 134.6 & 128.8 & 127.2 & 129.6 & 125.0 & 122.9 & 117.6 & 112.2 \\
\hline New York & 134.2 & 140.0 & 139.2 & 138.5 & 136.6 & 136.6 & 132.0 & 133.9 & 129.4 & 126.5 & 123.7 & 118.6 \\
\hline Pennsytvania & 121.4 & 126.6 & 125.1 & 124.1 & 125.2 & 420.3 & 117.4 & 119.6 & 115.9 & 111.1 & 106.0 & 101.6 \\
\hline Lower Arlantic (PADD IZ) & 126.5 & 132.5 & 129.6 & 127.3 & 126.6 & 121.4 & 118.3 & 118.1 & 113.1 & 109.3 & 103.9 & 99.7 \\
\hline North Carolina & 125.7 & 130.7 & 127.9 & 126.0 & 124.3 & 120.1 & 117.8 & 118.4 & 112.2 & 109.4 & 104.2 & 100.5 \\
\hline Virginia & 127.5 & 134.6 & 131.6 & 128.7 & 129.1 & 122.7 & 118.9 & 117.8 & 114.1 & 109.2 & 103.5 & 98.9 \\
\hline Midwest (PADD II) & 119.8 & 125.9 & 123.2 & 121.9 & $1 i 9.7$ & 111.3 & 107.3 & 109.6 & 103.0 & 97.6 & 92.0 & 89.3 \\
\hline & 120.5 & 126.5 & 120.8 & 118.9 & 116.9 & 107.7 & 103.3 & 105.3 & 99.0 & 92.5 & 88.0 & 85.2 \\
\hline Indiana & 123.0 & 129.5 & 123.0 & 123.0 & 120.2 & 110.2 & 107.2 & 111.2 & 102.6 & 98.1 & 91.6 & 89.5 \\
\hline lowa & 116.3 & 199.2 & 118.6 & 117.2 & 113.2 & 107.0 & 96.8 & 100.1 & 93.4 & 87.6 & 82.0 & 78.9 \\
\hline Michigan & 125.1 & 129.6 & 127.8 & 126.1 & 122.4 & 115.2 & 110.6 & 113.0 & 107.9 & 102.3 & 97.0 & 93.0 \\
\hline Minnesota & 116.9 & 124.3 & 124.5 & 124.2 & 122.5 & 112.8 & 108.9 & 111.8 & 103.6 & 98.0 & 90.9 & 89.1 \\
\hline Ohio & 122.3 & 129.0 & 124.8 & 120.7 & 120.2 & 113.2 & 107.6 & 108.4 & 102.2 & 97.0 & 91.8 & 89.6 \\
\hline Wisconsin & 115.7 & 122.0 & 120.1 & 119.8 & 117.7 & 109.5 & 107.6 & 109.3 & 103.5 & 98.5 & 93.4 & 90.8 \\
\hline
\end{tabular}

Pa Preliminary data.

$N A=$ Not available

Source: Based on data collected by Siate Exergy OHfices. 


\section{Table 7} Residential Propane Prices by Region and State
(Cents per Galion)

\begin{tabular}{|c|c|c|c|c|c|c|c|c|c|c|c|c|}
\hline \multirow[b]{2}{*}{ Fegion/stat } & \multicolumn{12}{|c|}{ 1990/91 Heating Season } \\
\hline & $10 / 01$ & $10 / 75$ & $11 / 05$ & $11 / 70$ & $12 / 03$ & $12 / 17$ & $01 / 07$ & $01 / 21$ & 02104 & $02 / 98$ & 03,04 & $03^{\prime} 18^{p}$ \\
\hline \multicolumn{13}{|c|}{ 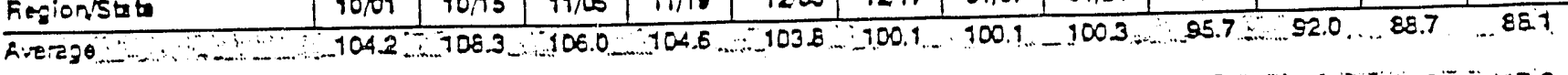 } \\
\hline \multicolumn{13}{|c|}{ 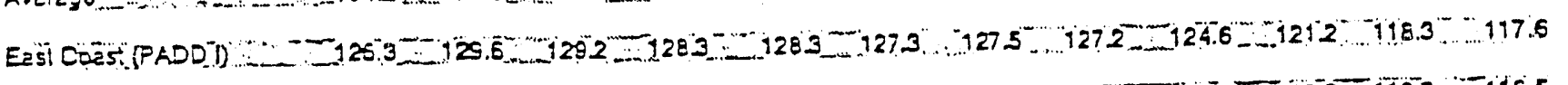 } \\
\hline \multicolumn{9}{|c|}{ 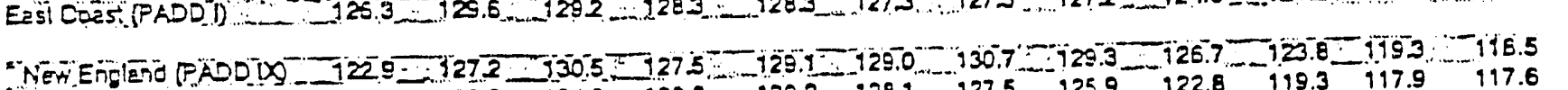 } & $-126.7=$ & & & \\
\hline Connezieut & 129.2 & 129.9 & 134.8 & 130.8 & 130.2 & 128.1 & 127.5 & 125.9 & 122.8 & 119.3 & 117.9 & 117.6 \\
\hline Mair & 119.9 & 121.6 & 127.4 & 123.7 & 1282 & 128.1 & 138.3 & 133.6 & 131.5 & 130.6 & 129.6 & 121.4 \\
\hline etts & 124.8 & 130.4 & 132.8 & 133.2 & 133.3 & 131.7 & 930.6 & 129.6 & 127.5 & 125.1 & 122.5 & 119.7 \\
\hline New & 123.5 & 128.1 & 132.5 & 123.3 & 124.6 & 128.3 & $12 E .8$ & $12 E .4$ & 123.3 & 119.3 & 117.7 & 113.7 \\
\hline & 132.0 & 134.8 & 139.9 & 141.0 & 1385 & 147.7 & 141.5 & 145.3 & 138.8 & 137.5 & 131.6 & 128.5 \\
\hline Vemont & 1172 & 126.3 & 125.0 & 126.5 & 128.7 & 128.0 & 128.4 & 129.7 & 126.7 & 122.4 & 115.3 & 199.2 \\
\hline \multicolumn{13}{|c|}{ 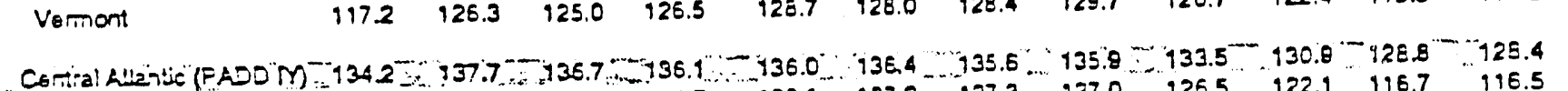 } \\
\hline Deiaware & 123.4 & 132.0 & 929.8 & 129.7 & 129.1 & 127.2 & 127.3 & 127.0 & 126.5 & 122.1 & 196.7 & 996.5 \\
\hline & 128.0 & 135.2 & 135.5 & 135.6 & 133.4 & 136.1 & 135.7 & 135.8 & 135.0 & 133.1 & 125.9 & 125.3 \\
\hline sey & 135.6 & 137.7 & 137.7 & 137.8 & 137.8 & 135.4 & 134.9 & 136.9 & 133.2 & 129.1 & 125 & 125.1 \\
\hline & 144.3 & 144.8 & 143.3 & 142.5 & 143.3 & 143.7 & 142.3 & 143.1 & 140.1 & 130.6 & 139.1 & 139.1 \\
\hline Fennsytvania & 119.9 & 135.8 & 124.8 & 123.4 & 123.5 & 124.0 & 123.4 & 122.0 & 120.1 & 1132 & 113.9 & 112.9 \\
\hline \multicolumn{13}{|c|}{ 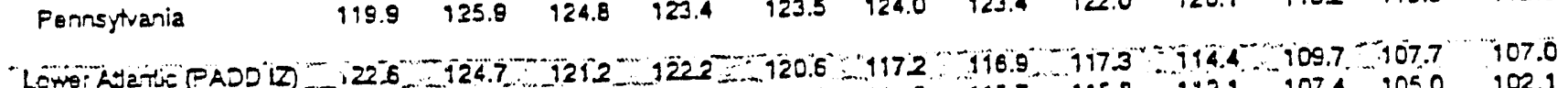 } \\
\hline $\begin{array}{l}\text { Lewsi. Ljatin Carolina } \\
\text { North }\end{array}$ & -122.7 & $\begin{array}{l}724.8 \\
125.8\end{array}$ & 120.4 & $-1222=$ & $\begin{array}{l}720.0 \div-1 \\
198.6\end{array}$ & 114.8 & 915.7 & 115.8 & 142.1 & 107.4 & 105.0 & 102.1 \\
\hline Virginia & 122.4 & 122.0 & 122.9 & 125.5 & 125.0 & 122.6 & 119.5 & 120.7 & 999.6 & 915.0 & 194.0 & 118.2 \\
\hline \multicolumn{13}{|c|}{ 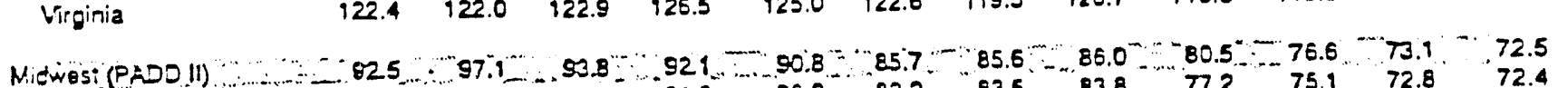 } \\
\hline Illinois & 83.8 & 96.7 & $82.4^{-}$ & 81.6 & $86.3^{-}$ & 82.2 & 03.5 & 83.8 & 772 & 75.1 & 72.8 & 72.4 \\
\hline Indiana & 92.8 & 89.5 & 89.4 & 99.5 & 99.2 & 95.8 & 96.7 & 95.8 & 93.2 & 90.6 & 89.2 & 87.8 \\
\hline & 78.5 & 83.8 & $\pi 73$ & 76.6 & 72.8 & 68.1 & 64.6 & 67.0 & 58.3 & 56.8 & 52.7 & 52.6 \\
\hline Kansas & 80.1 & 85.7 & 80.9 & 79.5 & 75.3 & 67.0 & 67.6 & 67.9 & 61.6 & 53.5 & 52.5 & 53.5 \\
\hline Michigan & 98.5 & 104.6 & 102.9 & 900.5 & 102.8 & 101.4 & 100.0 & 100.3 & 95.1 & 92.2 & 89.7 & 88.6 \\
\hline Minnesota & 99.2 & 101.9 & 96.8 & 93.6 & 59.4 & 87.1 & 86.5 & 88.9 & 82.2 & 79.5 & 75.3 & 75.7 \\
\hline Missouri & 80.1 & 95.8 & 824 & 88.8 & 87.5 & 83.5 & 82.4 & 81.4 & 76.5 & 72.2 & 69.0 & 68.1 \\
\hline Nebraska & 75.1 & 80.8 & 75.7 & 74.9 & 72.0 & 66.6 & 66.9 & 66.1 & 60.3 & 54.4 & 51.0 & 51.6 \\
\hline North Dakota & 77.2 & 82.2 & 79.5 & 78.9 & 78.5 & 72.8 & 75.8 & 77.0 & 71.4 & 63.7 & 57.4 & 54.8 \\
\hline Ohio & 113.5 & 119.4 & 918.4 & 198.3 & 116.1 & 113.6 & 196.6 & 118.9 & 115.6 & 191.7 & 104.1 & 101.8 \\
\hline South & 74.3 & 77.5 & 76.8 & 75.9 & 75.2 & 71.7 & 71.5 & 70.6 & 64.7 & 58.4 & 56.8 & 56.0 \\
\hline Wis =onsin & 97.7 & 101.6 & 100.4 & 97.2 & 98.3 & 91.1 & 91.9 & 90.0 & 85.2 & 81.1 & 77.7 & $\pi .1$ \\
\hline
\end{tabular}

P.Prellminary data.

Source: Based on data collected by State Energy Omces. 
Figure 6

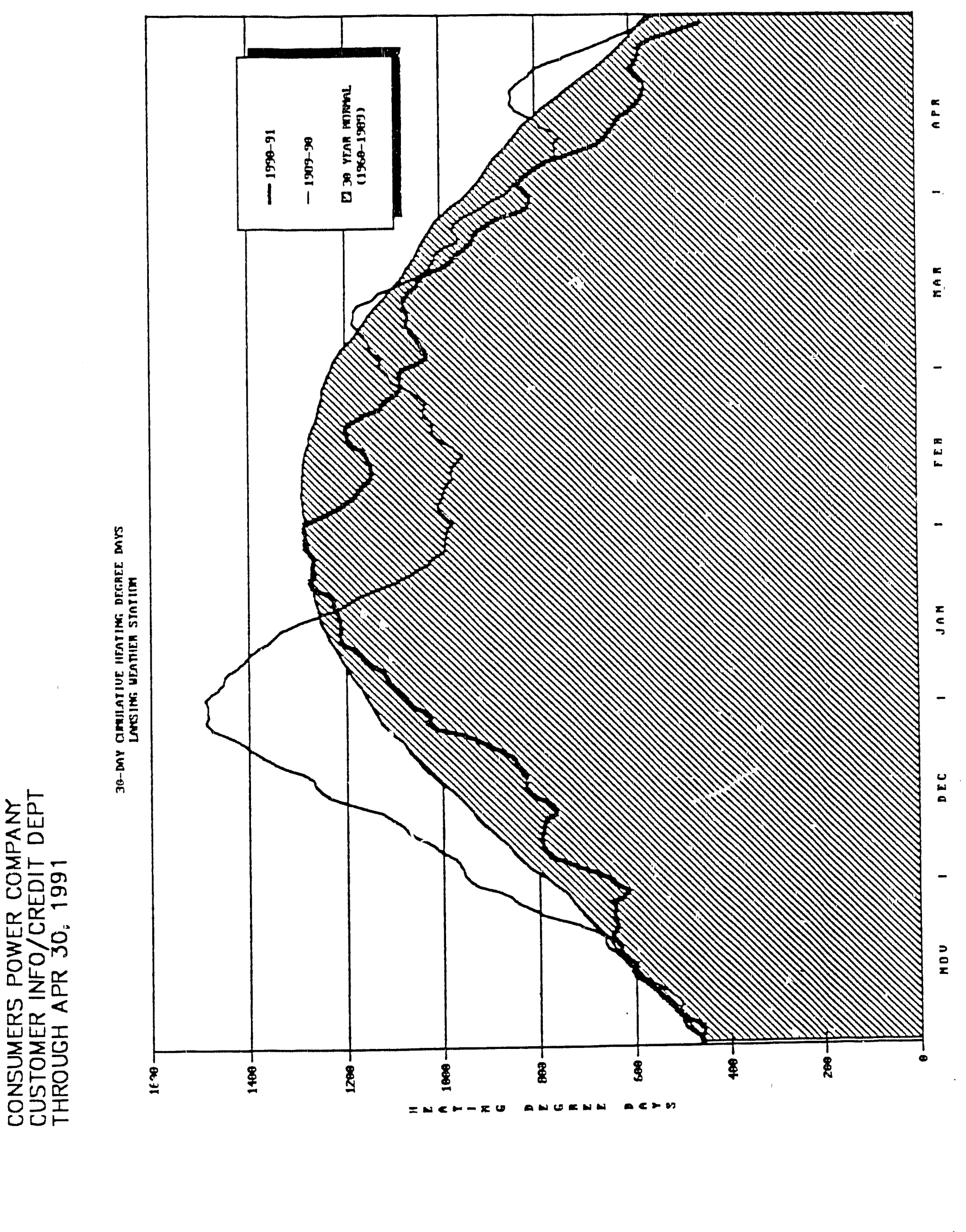


Page 16

Table 8

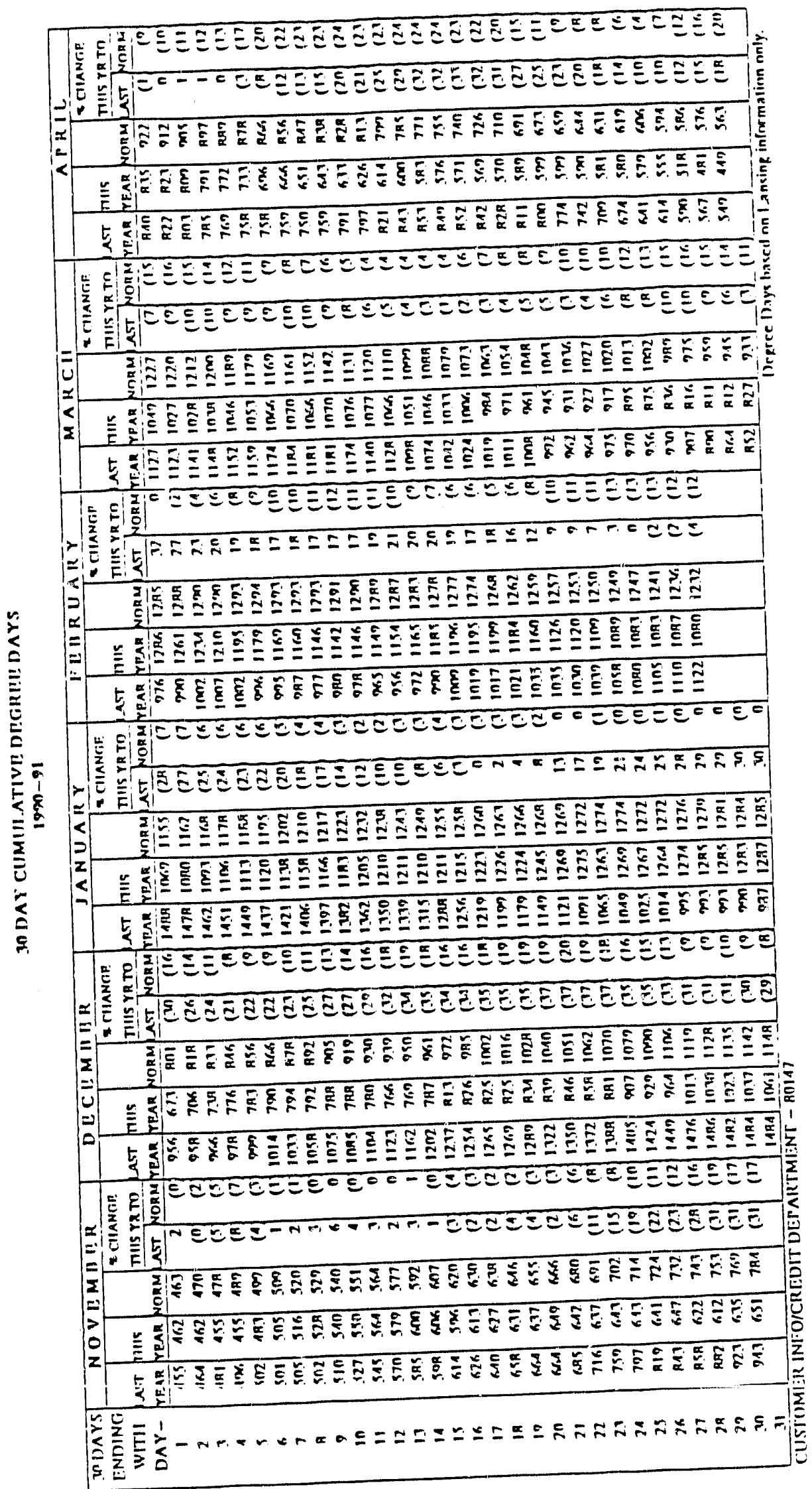



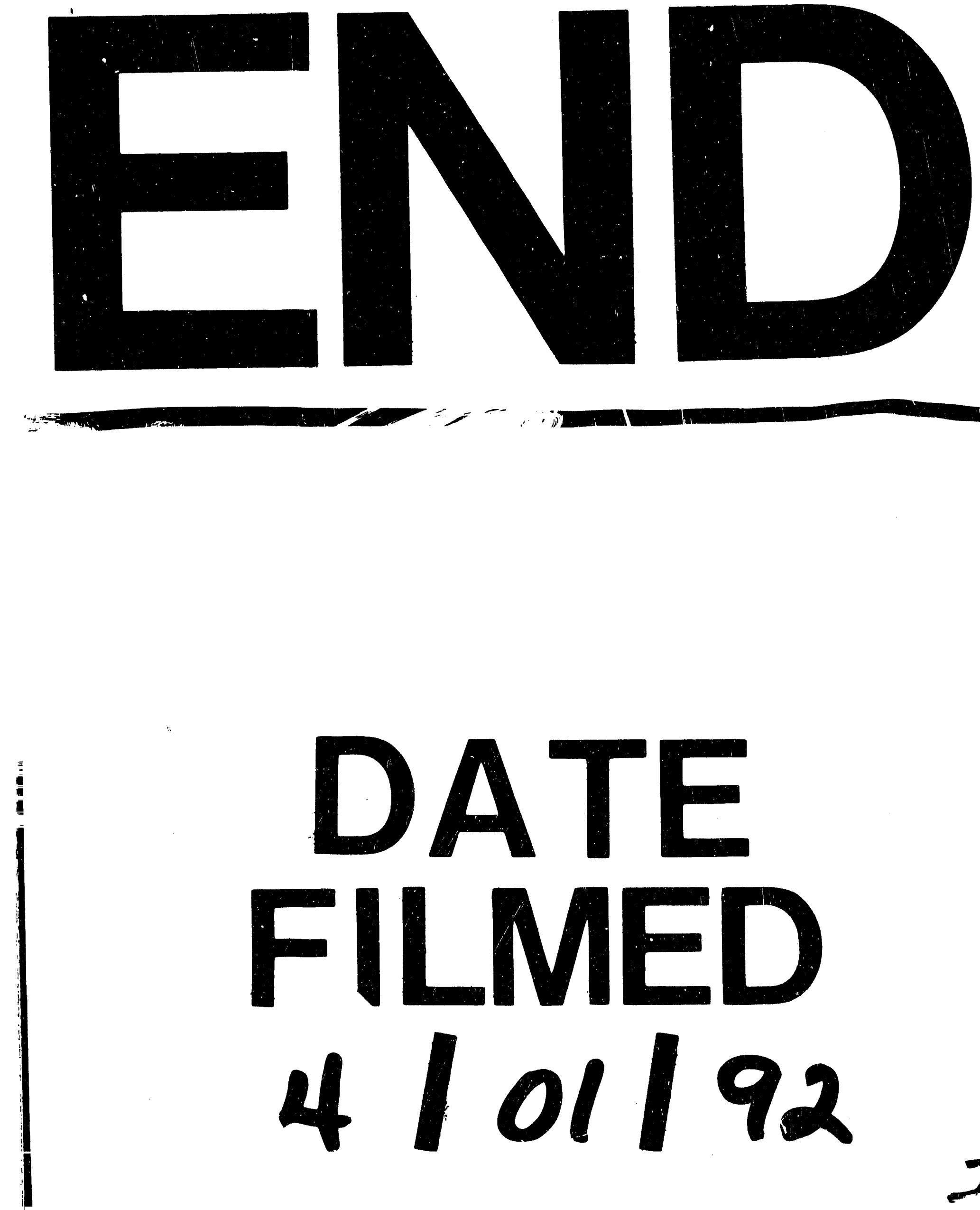

$I$ 


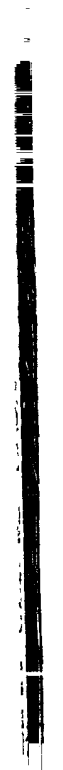

